\title{
Tamarix nilotica (Ehrenb) Bunge: A Review of Phytochemistry and Pharmacology \\ Ahmed AM Abdelgawad*
}

Department of Medicinal and Aromatic Plants, Desert Research Center, Cairo, 11753, Egypt

\begin{abstract}
Tamarix nilotica (Ehrenb.) Bunge is known as Nile Tamarisk belonging to the Tamaricaceae family. This plant has diverse and potential medicinal uses in traditional herbal medicine for treating relieve headache, draw out inflammation, and as an antiseptic agent in Egypt. Tamarix nilotica have been occurs in Lebanon, Palestine, Egypt, Sudan, Somalia, Ethiopia and Kenya. Phytochemical investigation revealed that the major chemical constituents of Tamarix nilotica are flavonoids, tannins and phenolics. The hydro-alcoholic extracts of the leaves of $T$. nilotica exhibited significant antioxidant, anti-tumor, hepatoprotective and antiviral activities.
\end{abstract}

Keywords: Tamarix nilotica; Nile Tamarisk; Ellagitannins; Flavonoids; Antioxidant; Antitumor; Antiviral; Hepatoprotective; Antimicrobial; Antidiabetic

\section{Introduction}

Tamaricaceae is relatively a small family of 4 genera and 120 species [1]. Members of the family are chiefly temperate and sub-tropical, growing in maritime or sandy habitats in addition to halophytes or xerophytes that are distributed from the Mediterranean, North Africa and south-western Africa through Arabian Peninsula to Central and South Asia [2].

The genus Tamarix (tamarisk, salt cedar) is composed of about 50-60 species of flowering plants in the family Tamaricaceae, native to drier areas of Eurasia and Africa. Tamarix is represented in Egypt with two indigenous species which are T. aphylla (L.) H. Karst and T. nilotica (Ehrenb.) Bunge while, it is represented by 8 species in Saudi Arabia, namely: T. mascatensis Bunge.; T. ramosissima Leded., T. nilotica (Ehrenb.) Bunge., T. aphylla L., T. tetragyna Ehrenb., T. aucheriana Decne., T. pyconocarpa DC and T. passerinoides Del [2-4]. Another species of Tamarix include T. arabica, T. aralensis, T. boveana, T. chinensis, T. hohenackeri, T. karelinii, T. kotschyi, T. leptopetala, T. laxa var. araratica, T. laxa var. subspicata, T. mannifera var. persica, T. pycnocarpa, T. hampeana, T. mascatensis, T. bengalensis, T. gallica var. arborea, T. mannifera var. purpurascens, T. passerinoides var. macrocarpa and T. pallasii var. macrostemon [5].

Several species of plants belonging to the genus Tamarix have been employed in traditional medicine. The common traditional uses shown in various reports for some plant species of the genus are as a diaphoretic, diuretic and hepatotonic and to treat liver disorders, relieve headache, ease prolonged or difficult labor, and cure sores and wounds besides being an astringent and employed for tanning and dyeing purposes [6-10].

Among Tamarix plants, Tamarix nilotica (Ehrenb.) Bunge is a native plant in Egypt with a long history. Its leaves and young branches were used for reducing spleen edema, and it is mixed with ginger for uterus infections, while an aqueous decoction of its bark with vinegar is used as a licicidal lotion [9]. The aim of this review is to compile and document information on different aspects of Tamarix nilotica and highlight the need for research and development.

\section{Botanical Description}

Tamarix nilotica (Ehrenb.) Bunge is described as shrubs or trees of 2-5 m; multiform, glabrous, glaucescent or green, leaves with free distinct blade, ovate or deltoid-cordate, acute, half-clasping. Foliage is variable: green or grayish, dotted or not, sometimes covered with salt crystals. Racemes are loose, also much variable in size and shape. Pedicel is shorter than the calyx; petals are obovate-oblong; stamens $4-5$; styles 3; capsule opening by 3 valves [11]. Seeds are numerous, elliptic with a tuft of hairs at the tip [3].

\section{Taxonomy}

The taxonomic classification of Tamarix nilotica is illustrated bellow [12,13]:
Kingdom: Plantae
Subkingdom: Tracheobionta
Division: Magnoliophyta
Class: Magnoliopsida
Order: Violales
Family: Tamaricaceae
Genus: Tamarix
Species: nilotica

\section{Vernacular Names}

The generic name originated in Latin: Tamarix may have referred to the Tamaris River in Hispania Tarraconensis (Spain) and nilotica, referred to the valley of the Nile. T. nilotica was known locally: in Egypt as Tarfa or Abal or Nile tamarisk; in Saudi Arabia and Palestine as Athel in Kenya as Uvari or Zizinda [14,15].

*Corresponding authors: Ahmed AM Abdelgawad, Department of Medicinal and Aromatic Plants, Desert Research Center, Cairo, 11753, Egypt, Tel: 0020119910661; E-mail: 9910661@gmail.com

Received January 16, 2017; Accepted February 01, 2017; Published February 08,2017

Citation: Abdelgawad AAM (2017) Tamarix nilotica (Ehrenb) Bunge: A Review of Phytochemistry and Pharmacology. J Microb Biochem Technol 9: 544-553. doi: 10.4172/1948-5948.1000340

Copyright: (c) 2017 Abdelgawad AAM. This is an open-access article distributed under the terms of the Creative Commons Attribution License, which permits unrestricted use, distribution, and reproduction in any medium, provided the original author and source are credited. 


\section{Geographical Distribution}

T. nilotica widespread in Egypt, growing in saline sandy soils, on the edges of salt marshes, coastal and inland sandy plains, and Nile banks $[4,16]$. T. nilotica occurs in Lebanon, Palestine, Egypt, Sudan, Somalia, Ethiopia and Kenya [15,17].

\section{Traditional Uses}

Tamarix nilotica has been known since pharaonic times and has been mentioned in medical papyri to expel fever, relieve headache, to draw out inflammation, and as an aphrodisiac aperient, sudorific, ulcer, expectorant, carminative, astringent, diuretic [9,18]. In Egyptian traditional medicine, it has been used as an antiseptic agent [19]. Different parts of T. nilotica are used; the leaves and young branches are cooked for oedema of spleen and mixed with ginger for uterus infections, while the bark, when boiled in water with vinegar is used as lotion against lice. The bark used to treat eyes sore from a scratch or blow, also it is used for hemorrhoid [20,21]. The wood yields a locally made charcoal, also used as a fuel, said to be good firewood; the timber is sometimes used for inferior carpentry. Tamarix nilotica can help stabilize sand and may form nabkhas as part of the dune forming process [22].

\section{Phytochemical Constituents}

T. nilotica is a rich source of different classes of natural products with varying structural patterns. Many compounds have been isolated from T. nilotica including carbohydrates, phenols, flavonoids, terpenoids, steroids, tannins, and cardiac glycosides. Total phenolic and flavonoid contents in their chemical equivalents (gallic acid and quercetin, respectively) of the different extracts of the flowers of $T$. nilotica collected from Ismailia road, Egypt, in October, 2011were reported as in Table 1 [9].

\section{Phenolics}

Many phenolic compounds include Nilocitin, Ellagic acid, Gallic acid and some derivatives were isolated from leaves, flowers, roots and the aerial parts of T. nilotica $[8,19,23-27]$. All the chemical constituents that have been reported in the literature from T. nilotica were listed in Table 2 (Figure 1).

\section{Flavonoids}

Flavonoids are common constituents of numerous plants world-

\begin{tabular}{|c|c|c|}
\hline Fraction & Total phenolic $\mathbf{( m g / g ~ G A E )}$ & Total flavonoid $\mathbf{( m g / g ~ Q E ) ~}$ \\
\hline Chloroform & $21.67 \pm 2.1$ & $0.79 \pm 2.4$ \\
\hline Ethyl acetate & $20.6 \pm 1$ & $1.75 \pm 1.5$ \\
\hline Butanol & $22.12 \pm 2.4$ & $0.58 \pm 2.3$ \\
\hline Aqueous & $17.2 \pm 1.4$ & - \\
\hline Total & $119.63 \pm 0.09$ & $2.55 \pm 0.19$ \\
\hline
\end{tabular}

Table 1: Phenolic and flavonoid contents in T. nilotica flowers.<smiles>[R][R]Oc1c(O)cc(C(=O)Oc2cc(C(C)(C)C)cc(O)c2[R2][R])cc1O</smiles><smiles>[R]C(=O)/C=C/c1ccc([R20])c([R20])c1</smiles>

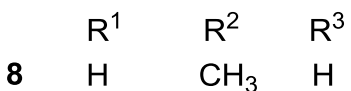

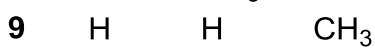

$\begin{array}{lllll}10 & \mathrm{OH} & \mathrm{H} & \mathrm{CH}_{3}\end{array}$

$11 \mathrm{OCH}_{3} \mathrm{H} \quad \mathrm{CH}_{3}$

$12 \mathrm{OCH}_{3} \quad \mathrm{CH}_{3} \quad \mathrm{OSO}_{2} \mathrm{H}$<smiles>[R20]Oc1cc2oc(=O)c3cc(O)c(O[R2])c4oc(=O)c(c1)c2c43</smiles><smiles>O=C(O)c1cc(O)c(O)c(Oc2c(C(=O)O)cc(O)c(O)c2O)c1</smiles><smiles>CCCCCCCCCOC(=O)COC(=O)C=Cc1ccc(O)c(OC)c1</smiles>

17<smiles>COc1cc(C2OCC3C(c4cc(OC)c(O)c(OC)c4)OCC23)cc(OC)c1O</smiles>

19<smiles>COc1cc(/C=C/C(=O)NCCc2ccc(O)cc2)ccc1O</smiles>

18<smiles>COc1cc(/C=C/CO)ccc1OS(=O)(=O)O</smiles>

3<smiles>[R20]CC1OC([R1])C(OC(=O)c2cc(O)c(O)c(O)c2)C([R2])C1O</smiles>

$$
\begin{array}{llll} 
& \mathrm{R}^{1} & \mathrm{R}^{2} & \mathrm{R}^{3} \\
1 & \text { Galloyl } & \mathrm{H} & \text { Galloyl } \\
16 & \mathrm{H} & \text { Galloyl } & \mathrm{H}
\end{array}
$$

Figure 1: The structure of phenolic compounds isolated from T. nilotica. 
Citation: Abdelgawad AAM (2017) Tamarix nilotica (Ehrenb) Bunge: A Review of Phytochemistry and Pharmacology. J Microb Biochem Technol 9: 544-553. doi: 10.4172/1948-5948.1000340

\begin{tabular}{|c|c|c|c|c|}
\hline \multicolumn{2}{|r|}{ Isolated compounds } & Extract/Fraction & Plant part & References \\
\hline \multicolumn{5}{|c|}{ Phenolics } \\
\hline 1 & 1,2,6-Tri-O-galloyl- $\beta$-D-glucose & $\mathrm{Aq} A \mathrm{Ac}$ & LP & [35] \\
\hline 2 & 3,4,8,9,10-pentahydroxy-dibenzo-[b,dlpyran-6-one & Aq Ac & $\mathrm{FP}$ & {$[23,24]$} \\
\hline 3 & Coniferyl alcohol 4-O-sulphate & $n$-Bu & LP & {$[26]$} \\
\hline 4 & Dehydrodigallic acid & Et Ac & $\mathrm{RP}$ & {$[19]$} \\
\hline 5 & Ellagic acid & $\mathrm{Aq} A c$ & FP & {$[23,24]$} \\
\hline 6 & Ellagic acid 3,3'-dimethyl ether 4-O- $\beta$-D-glucopyranoside & Et Ac & RP & {$[19]$} \\
\hline 7 & Ellagic acid-3-methyl ether & Et & AP & [8] \\
\hline 8 & Ferulaldehyde (4-hydroxy-3-methoxycinnamaldehyde) & Pet Eth & $\mathrm{RP}$ & [25] \\
\hline 9 & Isoferulaldehyde (3-hydroxy-4-methoxycinnamaldehyde) & Pet Eth & $\mathrm{RP}$ & {$[25]$} \\
\hline 10 & Isoferulic acid & $\mathrm{Bn}$ & $\mathrm{RP}$ & [19] \\
\hline 11 & Isoferulic acid methyl ester & Et & $\mathrm{AP}$ & [8] \\
\hline 12 & Methyl ferulate 3-O-sulphate & $n$-Bu & LP & [26] \\
\hline 13 & Gallic acid & Et Ac & $\mathrm{RP}$ & [19] \\
\hline 14 & Methyl gallate & Aq Ac & FP & {$[23,24]$} \\
\hline 15 & Methyl gallate 4-methylether & $\mathrm{Aq} \mathrm{Ac}$ & FP & {$[23,24]$} \\
\hline 16 & Nilocitin (2,3-digalloyl-D-glucopyranose) & Aq Ac & $\mathrm{FP}$ & {$[23,24]$} \\
\hline 17 & Niloticol (l-ferulloyl-3-pentacosanoylglycerol) & Pet Eth & $\mathrm{RP}$ & {$[25]$} \\
\hline 18 & $N$-trans-Feruloyltyramine & Et & AP & {$[8]$} \\
\hline 19 & Syringaresinol & $\mathrm{Bn}$ & $\mathrm{RP}$ & {$[19]$} \\
\hline \multicolumn{5}{|c|}{ Flavonoids } \\
\hline 20 & 5,7,4'-trihydroxy-5'-methoxylflavone & $\mathrm{Bu}$ & LP & {$[30]$} \\
\hline 21 & Flavone & $\mathrm{Bu}$ & LP & {$[31]$} \\
\hline 22 & Clematine & $\mathrm{Et}$ & AP & [8] \\
\hline 23 & Dihydroflavonol & $\mathrm{Bu}$ & LP & {$[31]$} \\
\hline 24 & Dillenetin & $\mathrm{Et}$ & AP & [8] \\
\hline 25 & Kaempferide & Et & AP & [8] \\
\hline 26 & Kaempferol & $\begin{array}{c}n-\mathrm{Bu} \\
\mathrm{Et}\end{array}$ & $\begin{array}{l}\text { LP } \\
\text { LP }\end{array}$ & $\begin{array}{l}{[26]} \\
{[28]}\end{array}$ \\
\hline 27 & Kaempferol-3-glucoside(Astragalin) & $\begin{array}{c}\mathrm{Aq} A c \\
\text { Et }\end{array}$ & $\begin{array}{l}\text { FP } \\
\text { LP }\end{array}$ & $\begin{array}{l}{[29]} \\
{[28]}\end{array}$ \\
\hline 28 & Kaempferol 3-O-sulphate-7,4'-dimethyl ether & $\mathrm{Aq} A \mathrm{Ac}$ & FP & {$[29]$} \\
\hline 29 & Kaempferol 3-O- $\beta$-D-glucuronide 6"-ethyl ester & $\mathrm{Aq} \mathrm{Ac}$ & $\mathrm{FP}$ & {$[29]$} \\
\hline 30 & Kaempferol-4', 7-dimethyl ether & $\begin{array}{c}\mathrm{Aq} \mathrm{Ac} \\
\mathrm{Et}\end{array}$ & $\begin{array}{l}\text { FP } \\
\text { LP }\end{array}$ & $\begin{array}{l}{[29]} \\
{[28]}\end{array}$ \\
\hline & & $\mathrm{Et}$ & AP & [8] \\
\hline 31 & Kaempferol-4', 7-dimethyl ether-3-glucoside & Et & LP & {$[28]$} \\
\hline 32 & Naringenin & Et & AP & {$[8]$} \\
\hline 33 & Quercetin & $\mathrm{Aq} \mathrm{Ac}$ & FP & [29] \\
\hline
\end{tabular}


Citation: Abdelgawad AAM (2017) Tamarix nilotica (Ehrenb) Bunge: A Review of Phytochemistry and Pharmacology. J Microb Biochem Technol 9: 544-553. doi: 10.4172/1948-5948.1000340

\begin{tabular}{|c|c|c|c|c|}
\hline 34 & Quercetin 3-O- $\beta$-D-glucupyranuronide & $n-\mathrm{Bu}$ & LP & [26] \\
\hline 35 & Quercetin 3-O- $\beta$-D-glucuronide 6"-ethyl ester & $\mathrm{Aq} A c$ & FP & [29] \\
\hline 36 & Quercetin 3-O- $\beta$-D-glucuronide 6"-methyl ester & $\mathrm{Aq} A c$ & FP & [29] \\
\hline 37 & Quercetin-3-glucoside(Isoquercitrin) & Et & LP & [28] \\
\hline 38 & Tamarixetin & $n-\mathrm{Bu}$ & LP & [26] \\
\hline \multirow[t]{2}{*}{39} & Tamarixin (tamarixetin-3-glucoside) & Et & LP & [28] \\
\hline & \multicolumn{3}{|l|}{ Ellagitannins } & \\
\hline 40 & 1,3-Di-O-galloyl-4,6-O-(S)-hexahydroxydiphenoyl- $\beta$-D-glucose & $\mathrm{Aq} A \mathrm{c}$ & LP & [34] \\
\hline 41 & Gemin D & $\mathrm{Aq} A c$ & LP & [34] \\
\hline 42 & Hippomanin A & $\mathrm{Aq} \mathrm{Ac}$ & LP & [34] \\
\hline 43 & Hirtellin A & $\mathrm{Aq} A c$ & LP & [34] \\
\hline 44 & Hirtellin B & $\mathrm{Aq} A c$ & LP & [35] \\
\hline 45 & Hirtellin C & $\mathrm{Aq} A \mathrm{c}$ & LP & [35] \\
\hline 46 & Hirtellin D & $\mathrm{Aq} A \mathrm{c}$ & LP & [37] \\
\hline 47 & Hirtellin F & $\mathrm{Aq} A c$ & LP & [35] \\
\hline 48 & Hirtellin T1 & $\mathrm{Aq} A \mathrm{c}$ & LP & [10] \\
\hline 49 & Hirtellin T2 & $\mathrm{Aq} A c$ & LP & [37] \\
\hline 50 & Hirtellin T3 & $\mathrm{Aq} A \mathrm{c}$ & LP & [10] \\
\hline 51 & Isohirtellin C & $\mathrm{Aq} A c$ & LP & [35] \\
\hline 52 & Nilotinin D1 & $\mathrm{Aq} A \mathrm{c}$ & LP & [34] \\
\hline 53 & Nilotinin D2 & $\mathrm{Aq} A c$ & LP & [34] \\
\hline 54 & Nilotinin D3 & $\mathrm{Aq} A c$ & LP & [34] \\
\hline 55 & Nilotinin D4 & $\mathrm{Aq} A \mathrm{c}$ & LP & [36] \\
\hline 56 & Nilotinin D5 & $\mathrm{Aq} A c$ & LP & [36] \\
\hline 57 & Nilotinin D6 & $\mathrm{Aq} A c$ & LP & [36] \\
\hline 58 & Nilotinin D7 & $\mathrm{Aq} A \mathrm{c}$ & LP & [35] \\
\hline 59 & Nilotinin D8 & $\mathrm{Aq} A c$ & LP & [35] \\
\hline 60 & Nilotinin D9 & $\mathrm{Aq} A c$ & LP & [35] \\
\hline 61 & Nilotinin D10 & $\mathrm{Aq} A \mathrm{c}$ & LP & [37] \\
\hline 62 & Nilotinin M1 & $\mathrm{Aq} A c$ & LP & [34] \\
\hline 63 & Nilotinin M2 & $\mathrm{Aq} A c$ & LP & [36] \\
\hline 64 & Nilotinin M3 & $\mathrm{Aq} A c$ & LP & [36] \\
\hline 65 & Nilotinin M4 & $\mathrm{Aq} A c$ & LP & [35] \\
\hline 66 & Nilotinin M5 & $\mathrm{Aq} A c$ & LP & [37] \\
\hline 67 & Nilotinin M6 & $\mathrm{Aq} A c$ & LP & [37] \\
\hline 68 & Nilotinin M7 & $\mathrm{Aq} A c$ & LP & [37] \\
\hline 69 & Nilotinin Q1 & $\mathrm{Aq} A c$ & LP & [10] \\
\hline 70 & Nilotinin T1 & $\mathrm{Aq} A c$ & LP & [37] \\
\hline 71 & Nilotinin T2 & $\mathrm{Aq} A c$ & LP & [10] \\
\hline 72 & Nilotinin T3 & $\mathrm{Aq} A c$ & LP & [10] \\
\hline 73 & Remurin A & $\mathrm{Aq} A c$ & LP & [34] \\
\hline 74 & Remurin B & $\mathrm{Aq} A c$ & LP & [34] \\
\hline 75 & Tamarixinin A & $\mathrm{Aq} A c$ & LP & [35] \\
\hline 76 & Tamarixinin B & $\mathrm{Aq} A c$ & LP & [37] \\
\hline
\end{tabular}




\begin{tabular}{|c|c|c|c|c|}
\hline 77 & Tamarixinin C & $A c$ & LP & [37] \\
\hline 78 & Tellimagrandin I & $\mathrm{Aq} \mathrm{Ac}$ & LP & [35] \\
\hline 79 & Tellimagrandin II & $\mathrm{Aq} A c$ & LP & [35] \\
\hline \multicolumn{5}{|c|}{ Terpenoids } \\
\hline 80 & 3-O-trans-caffeoylisomyricadiol & Et & AP & [8] \\
\hline 81 & 3a-(3",4"-dihydroxy-trans-cinnamoyloxy)-D-friedoolean-14-en-28-oic acid & $n-\mathrm{Hn}$ & LP & {$[26,27]$} \\
\hline \multicolumn{5}{|c|}{ Steroids } \\
\hline 82 & $\beta$-Sitosterol & Et & AP & [8] \\
\hline
\end{tabular}

Table 2: Isolated compounds from the different parts of T. nilotica.

LP: Leaves Parts; FL: Flowers Parts; RP: Roots Parts; AP: Aerial Parts; Aq Ac: Aqueous Acetone; Pet Eth: Petroleum Ether; Bn: Benzene; $n$-Bu: $n$-Butanol; $n$-Hn: $n$-Hexane; Et Ac: Ethyl Acetate; Et: Ethanol; Bu: Butanol

wide. The flavonoids isolated from the aerial parts of T. nilotica include kaempferol, tamarixetin, quercetin, isoquercitrin, flavone, naringenin, dillenetin and its derivatives T. nilotica [8,26,28-31]. Flavonoids are the mostly biological active compounds found in plants, they are widely used in a variety of nutraceutical, cosmetic and pharmaceutical applications [32] (Figure 2).

\section{Ellagitannins}

The tamaricaceous plants produce a unique class of ellagitannins with diverse structures [33]. The review of literature reported the isolation of monomeric (Isohirtellin C, Remurin A-B, Gemin D, Nilotinin, Nilotinin M2-7, Hippomanin A, and Tellimagrandin I-II), dimeric (Nilotinins D1-D10, Tamarixinin A-C and Hirtellin A-D and F), trimeric (Nilotinin T1-T2, Hirtellin T1-T3) and tetrameric ellagitannins (Nilotinin Q1) from the aqueous acetone extracts of leaves of T. nilotica growing in Egypt [10,34-37]. Interest in the ellagitannin constituents due to their marked antiviral, antimicrobial, immunomodulatory, antitumor, and hepatic protective activities, which are largely dependent on the tannin structures [38] (Figure 3).

\section{Terpenoids and steroids}

To date, two terpenoids and one steroid compounds from $T$. nilotica have been reported. In 2009, 3a-(3",4"-dihydroxy-transcinnamoyloxy)-D-friedoolean-14-en-28-oic acid, was isolated from the leaves of T. nilotica growing in Egypt [26]. Furthermore, 3-O-transcaffeoylisomyricadiol and $\beta$-sitosterol were isolated from the ethanolic extract of the aerial parts of T. nilotica growing in Saudi Arabia [8] (Figure 4).

\section{Pharmacological Activities}

Scientific studies on T. niloyica indicate that it has wide-reaching pharmacological activities, including the effects as anti-tumor, antioxidant, antidiabetic, antiviral, antimicrobial and hepatoprotective activity.

\section{Antioxidant activity}

Free radicals are involved in a number of pathological conditions such as inflammatory diseases, atherosclerosis, cerebral ischemia, AIDS, and cancer [39]. The free radicals are produced in the human body due to environmental pollutants, chemicals, physical stress, radiations, etc. Catalase and hydroperoxidase enzymes are among the important antioxidants produced by the immune system. Consumption of antioxidants or free radical scavengers is necessary to compensate depletion of antioxidants of the immune system.

In 2008, AbouZid et al., reported that, the aqueous alcoholic extracts of leaves and flowers of Tamarix nilotica grown in Egypt had a significant antioxidant activity (73-96\%) [7]. The in vitro antioxidant assays used in this study were 1,1-diphenyl-2-picryl hydrazyl (DPPH) radical scavenging activity, superoxide anion scavenging activity and iron chelating activity $[26,40]$.

DPPH free radical scavenging activity of different T. nilotica subextracts has been screened at $100 \mu \mathrm{g} / \mathrm{ml}$. EtOAc (100\%), $\mathrm{BuOH}(93 \%)$ and total extract (90\%) exhibited potential antioxidant activity while $\mathrm{CHCl} 3$ exhibited the lowest effect (26\%). Comparing the IC50 of promising subextracts $(>90 \%)$ with ascorbic acid as positive control (IC50 $4.8 \pm 0.54 \mu \mathrm{g} / \mathrm{ml})$, EtOAc showed the best effect $(7.25 \pm 0.86 \mu \mathrm{g} /$ $\mathrm{ml})$, with lower IC50 followed by $\mathrm{BuOH}(8.25 \pm 0.65 \mu \mathrm{g} / \mathrm{ml})$ and total extract $(45 \pm 0.73 \mu \mathrm{g} / \mathrm{ml})$ [9]. When antioxidant assay was performed by TLC using DPPH, a significant antioxidant activity was related to butanol fractions of Tamarix nilotica grown in Sudan [31].

\section{Cytotoxic and anti-angiogenic activity}

Ellagitannins from the leaves of T. nilotica grown in Egypt were reported to exhibit significant host-mediated antitumor activities against sarcoma-180 in mice and strong cytotoxic effects with higher tumor specificity against four tumor cell lines $[35,37]$. T. nilotica showed a selective cytotoxic potential against liver (HUH-7), colon (HCT-116), lung and breast (MCF-7) carcinoma cell, while being non-toxic to other cancer cells $[9,40]$.

A considerable number of cancers have been reported to be dependent on angiogenesis and respond well to anti-angiogenic therapies. These include cancers of the colon, breast, lung, and bladder as well as renal cell carcinoma and non-small cell lung cancer (NSCLC). Anti-angiogenic therapies target angiogenesis by two major mechanisms: blocking the receptor tyrosine kinases intracellularly or neutralizing angiogenic factors such as VEGF or its receptors [41].

The results indicated that the leaves extract of Tamarix nilotica grown in Sudan exhibited remarkable anti-angiogenic activity by inhibiting the sprouting of micro-vessels more than $60 \%$ by using ex vivo rat aortic ring assay [42]. 


\section{Hepatoprotective activity}

Hepatoprotective activity of T. nilotica grown in Egypt was assessed using carbon tetrachloride- induced hepatic injury in rats by monitoring biochemical parameters. Aqueous ethanol extract of flowers of T. nilotica ameliorated the adverse effects of carbon tetrachloride and returned the altered levels of biochemical markers near to the normal levels [40]. In this study, carbon tetrachloride was used to induce liver damage and hence enhancing the levels of SGOT, SGPT and ALP. Carbon tetrachloride is biotransformed by liver enzymes to a highly reactive free radical. This free radical can lead to lipid peroxidation, disruption of $\mathrm{Ca}^{2+}$ homeostasis, elevation of hepatic enzymes, and finally results in cell death [43]. Carbon tetrachloride has been used in animal models to investigate chemical toxininduced liver damage. The extent of hepatic damage is assessed by the increased level of cytoplasmic enzymes (SGOT, SGPT and ALP).

\section{Antidiabetic activity}

The leaves aqueous extracts of T. nilotica were used effectively to reduce the serum glucose level as the experimental period progressed and demonstrated a marked hypolipidemic effect evidenced by the lower serum triglyceride and total cholesterol levels. The overall effect of the plant extracts was significantly better than the synthetic drug, metformin in terms of antihyperglycemia and antihyper triacylglycerolaemia. Also, the results suggest that the plant extract are potential phytotherpeutic agents which could be used for the management of diabetes type 2 and dyslipidemia associated with it [44]. The hypoglycemic activity may result from both pancreatic and extrapancreatic mechanisms, on the other hand, enhanced by high antioxidant capacity [45]. The actual role of these interesting compounds in the antidiabetic properties of T. nilotica still requires elucidation. These polyphenolic compounds act as monomers or oligomers, responsible for in vitro insulin enhancing activity in epididymal fat cells and shown in vitro to have insulin-like activity as well as an antioxidant effect.

\section{Antiviral effect}

Infectious viral diseases are still major threat to public health and remain as an important problem due to viruses have resisted prophylaxis or therapy longer than any other form of life [46]. Egyptian medicinal plants have diverse uses in traditional folk medicine to cure various ailments including infectious diseases.

The Hydro-alcoholic extracts of the aerial parts of Tamarix nilotica are found to have virucidal effect against herpes simplex-1 virus (HSV) at concentration of $1000 \mu \mathrm{g} / \mathrm{ml}$ with $\mathrm{Rf} 10^{4}$ [47]. The antiviral bioassay is carried out by the end point titration technique (EPTT) that builds on the ability of plant extract dilutions to inhibit the produced cytopathogenic effect (CPE) and expressed as reduction factor (Rf) of the viral titer.

\section{Antimicrobial activity}

A significant antibacterial and antifungal activity was related to<smiles>[R]c1cc([R])c2c(=O)c([R])c(-c3ccc([R])c([R4])c3)oc2c1</smiles>

\begin{tabular}{|c|c|c|c|c|c|}
\hline & $\mathrm{R}^{1}$ & $\mathrm{R}^{2}$ & $\mathrm{R}^{3}$ & $\mathrm{R}^{4}$ & $\mathrm{R}^{5}$ \\
\hline 22 & $\mathrm{H}$ & $\mathrm{OH}$ & $\mathrm{OH}$ & $\mathrm{OH}$ & $\mathrm{OCH}_{3}$ \\
\hline 23 & $\mathrm{H}$ & $\mathrm{H}$ & $\mathrm{H}$ & $\mathrm{H}$ & $\mathrm{H}$ \\
\hline 25 & $\mathrm{OH}$ & $\mathrm{OH}$ & $\mathrm{OH}$ & $\mathrm{OCH}_{3}$ & $\mathrm{OCH}_{3}$ \\
\hline 26 & $\mathrm{OH}$ & $\mathrm{OH}$ & $\mathrm{OH}$ & $\mathrm{H}$ & $\mathrm{OCH}_{3}$ \\
\hline 27 & $\mathrm{OH}$ & $\mathrm{OH}$ & $\mathrm{OH}$ & $\mathrm{H}$ & $\mathrm{OH}$ \\
\hline 28 & OG & $\mathrm{OH}$ & $\mathrm{OH}$ & $\mathrm{H}$ & $\mathrm{OH}$ \\
\hline 29 & $\mathrm{OSO}_{3} \mathrm{H}$ & $\mathrm{OH}$ & $\mathrm{OCH}_{3}$ & $\mathrm{H}$ & $\mathrm{OC}$ \\
\hline 30 & OGREE & $\mathrm{OH}$ & $\mathrm{OH}$ & $\mathrm{H}$ & $\mathrm{OH}$ \\
\hline 31 & $\mathrm{OH}$ & $\mathrm{OH}$ & $\mathrm{OCH}_{3}$ & $\mathrm{H}$ & $\mathrm{OCH}_{3}$ \\
\hline 32 & OG & $\mathrm{OH}$ & $\mathrm{OCH}_{3}$ & $\mathrm{H}$ & $\mathrm{OCH}$ \\
\hline 34 & $\mathrm{OH}$ & $\mathrm{OH}$ & $\mathrm{OH}$ & $\mathrm{OH}$ & $\mathrm{OH}$ \\
\hline
\end{tabular}

where: $\mathrm{G}=$ glucoside; $\mathrm{GP}=-\beta$-D-glucupyranuronide; GREE = - $\beta$-D-glucuronide 6"-ethyl ester; GRME $=-\beta$-D-glucuronide 6"-methyl ester

$\begin{array}{llllll} & \mathrm{R}^{1} & \mathrm{R}^{2} & \mathrm{R}^{3} & \mathrm{R}^{4} & \mathrm{R}^{5} \\ \mathbf{3 5} & \mathrm{OGP} & \mathrm{OH} & \mathrm{OH} & \mathrm{OH} & \mathrm{OH} \\ \mathbf{3 6} & \text { OGREE } & \mathrm{OH} & \mathrm{OH} & \mathrm{OH} & \mathrm{OH} \\ \mathbf{3 7} & \mathrm{OGRME} & \mathrm{OH} & \mathrm{OH} & \mathrm{OH} & \mathrm{OH} \\ \mathbf{3 8} & \mathrm{OG} & \mathrm{OH} & \mathrm{OH} & \mathrm{OH} & \mathrm{OH} \\ \mathbf{3 9} & \mathrm{OH} & \mathrm{OH} & \mathrm{OH} & \mathrm{OH} & \mathrm{OCH}_{3} \\ \mathbf{4 0} & \mathrm{OG} & \mathrm{OH} & \mathrm{OH} & \mathrm{OH} & \mathrm{OCH}_{3}\end{array}$

Figure 2: The structure of flavonoid compounds isolated from T. nilotica. 


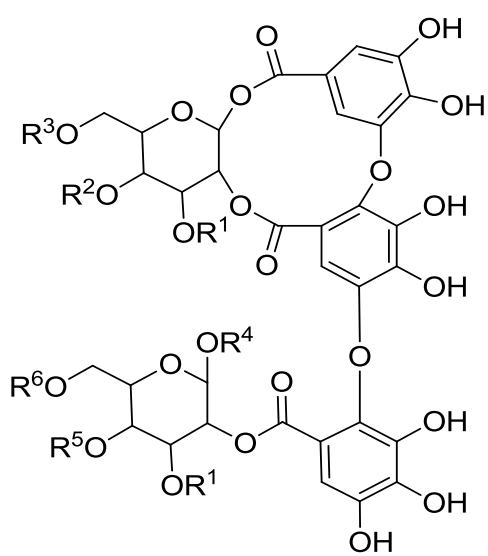

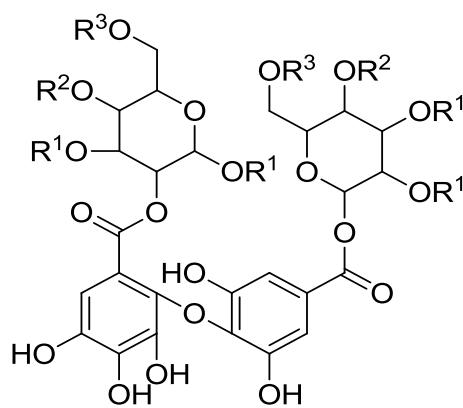

$77 \mathrm{R}^{1}=\mathrm{Gal}, \mathrm{R}^{2}+\mathrm{R}^{3}=\mathrm{HHDP}$

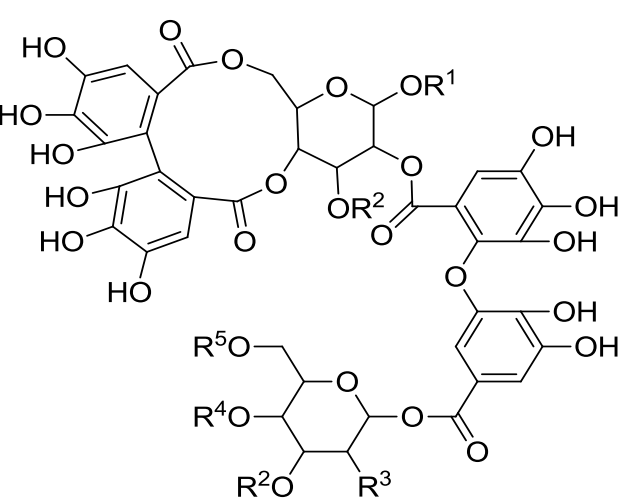

$\begin{array}{lllll}R^{1} & R^{2} & R^{3} & R^{4} & R^{5}\end{array}$

43 Gal Gal Gal $R^{4}+R^{5}=H H D P$

52 Gal Gal $\mathrm{H} \quad \mathrm{R}^{4}+\mathrm{R}^{5}=\mathrm{HHDP}$

$53 \mathrm{H} \quad \mathrm{Gal} \quad \mathrm{H} \quad \mathrm{R}^{4}+\mathrm{R}^{5}=\mathrm{HHDP}$

$54 \mathrm{H}$ Gal Gal $\mathrm{R}^{4}+\mathrm{R}^{5}=\mathrm{HHDP}$

57 Gal Gal Gal $H$ H

61 Gal Gal DHDG H H

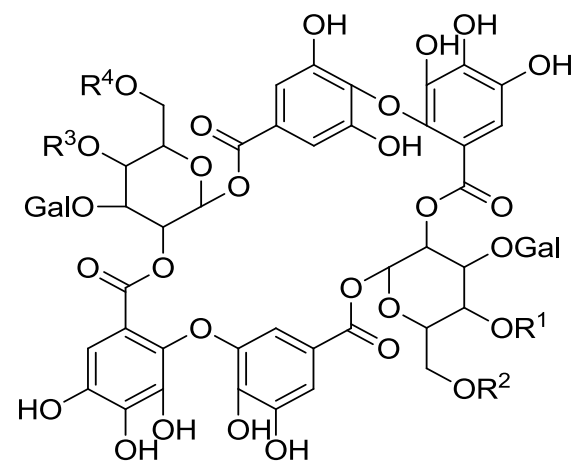

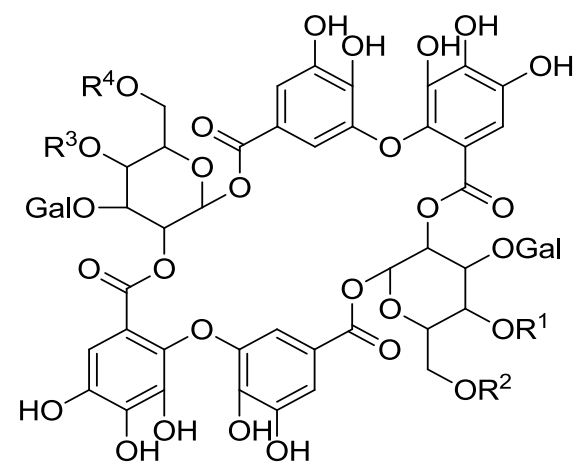

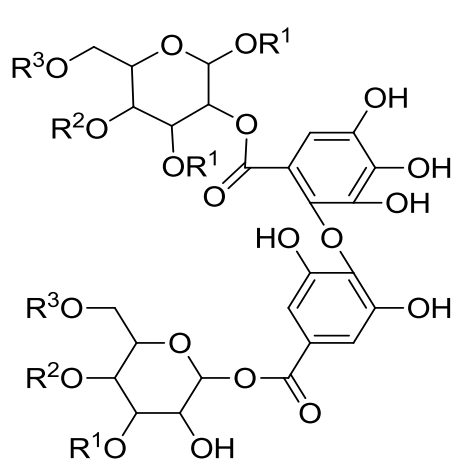

$45 \mathrm{R}^{1}+\mathrm{R}^{2}=\mathrm{HHDP}, \mathrm{R}^{3}+\mathrm{R}^{4}=\mathrm{HHDP}$

$47 \quad R^{1}=H, R^{2}=H, \quad R^{3}+R^{4}=H H D P$

$60 R^{1}+R^{2}=H H D P, R^{3}=H, R^{4}=H$
$R^{1} \quad R^{2}$
$R^{3} \quad R^{4}$
46
$\mathrm{H} \quad \mathrm{H}$
$\mathrm{R}^{3}+\mathrm{R}^{4}=\mathrm{HHDP}$
$51 \mathrm{R}^{1}+\mathrm{R}^{2}=\mathrm{HHDP} \quad \mathrm{R}^{3}+\mathrm{R}^{4}=\mathrm{HHDP}$

$55 \mathrm{R}^{1}=\mathrm{Gal}, \mathrm{R}^{2}+\mathrm{R}^{3}=\mathrm{HHDP}$

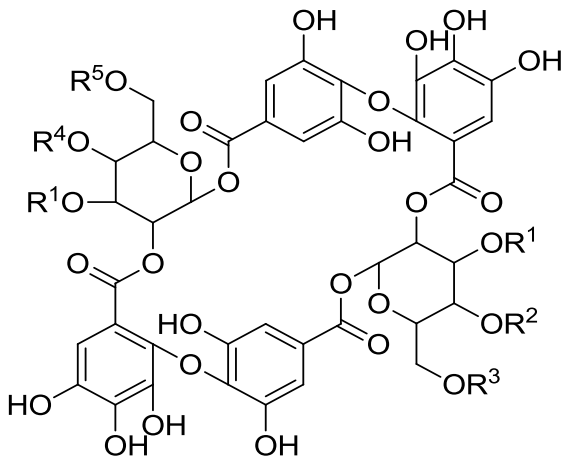

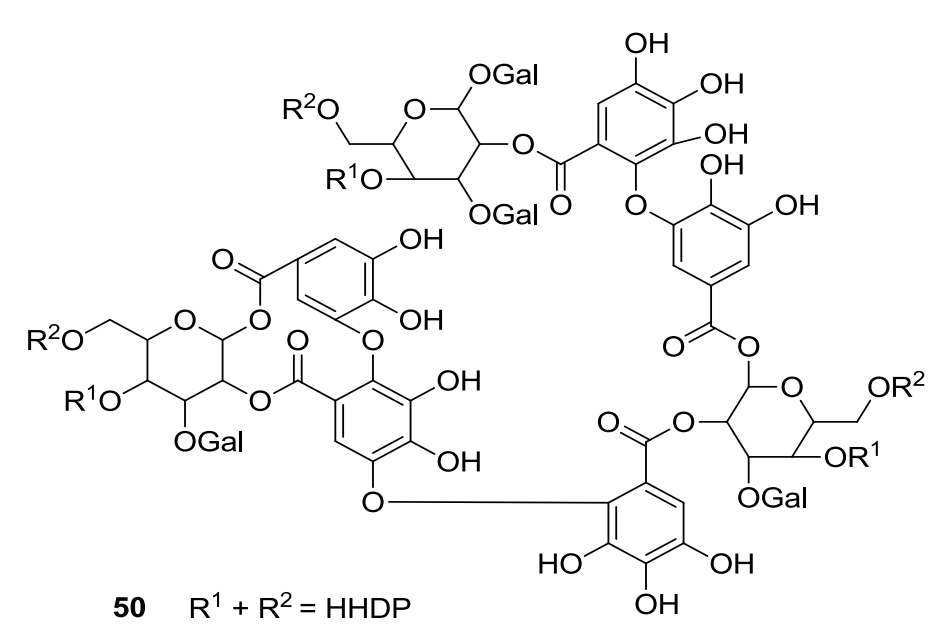

$50 \quad \mathrm{R}^{1}+\mathrm{R}^{2}=\mathrm{HHDP}$ 


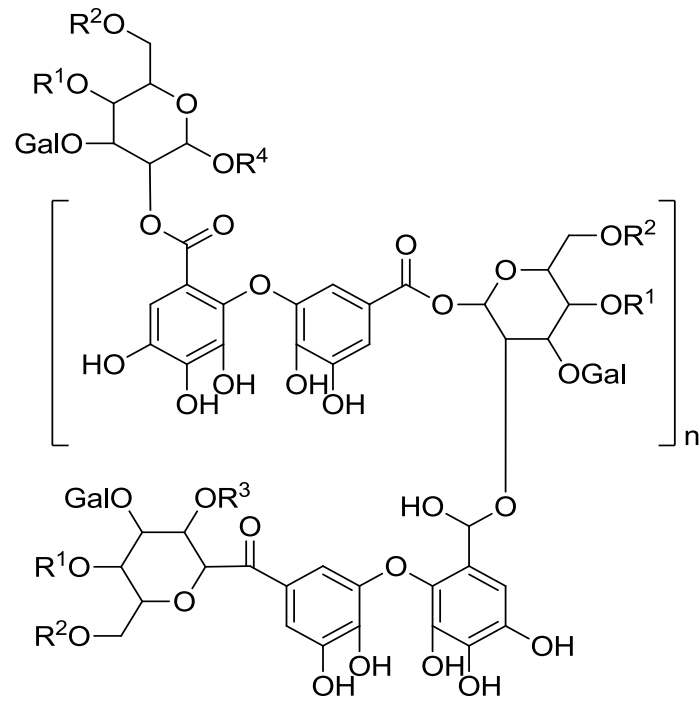<smiles>[R]C1OC2COC(=O)c3cc(O)c(O)c(O)c3-c3c(cc(O)c(O)c3O)C(=O)OC2C(O)C1[R]</smiles>

\begin{tabular}{|c|c|c|c|c|c|c|c|}
\hline & $\mathrm{R}^{1}$ & $\mathrm{R}^{2}$ & $\mathrm{R}^{3}$ & & $\mathrm{R}^{1}$ & $\mathrm{R}^{2}$ & $\mathrm{R}^{3}$ \\
\hline 40 & Gal & $\mathrm{H}$ & Gal & 67 & isoDHDG & isoDHDG & Gal \\
\hline 41 & $\mathrm{H}$ & $\mathrm{H}$ & Gal & 68 & Gal & isoDHDG & Gal \\
\hline 42 & $\mathrm{H}$ & Gal & $\mathrm{H}$ & 73 & Gal & DHDG & Gal \\
\hline 62 & $\mathrm{H}$ & isoDHDG & Gal & 74 & $\mathrm{H}$ & DHDG & Gal \\
\hline 63 & $\mathrm{CH}_{3}$ & DHDG & Gal & 78 & $\mathrm{H}$ & Gal & Gal \\
\hline 64 & isoDHDG & $\mathrm{H}$ & Gal & 79 & $\mathrm{H}$ & Gal & Gal \\
\hline 66 & isoDHDG & DHDG & Gal & & & & \\
\hline
\end{tabular}

48, $n=1, R^{1}+R^{2}=H H D P, \quad R^{3}=$ Gal, $R^{4}=$ Gal

71, $n=1, R^{1}+R^{2}=H H D P, \quad R^{3}=H, \quad R^{4}=$ Gal

69, $n=2, R^{1}+R^{2}=H H D P, \quad R^{3}=H, \quad R^{4}=$ Gal

72, $n=1, R^{1}+R^{2}=H H D P, \quad R^{3}=G a l, R^{4}=H$

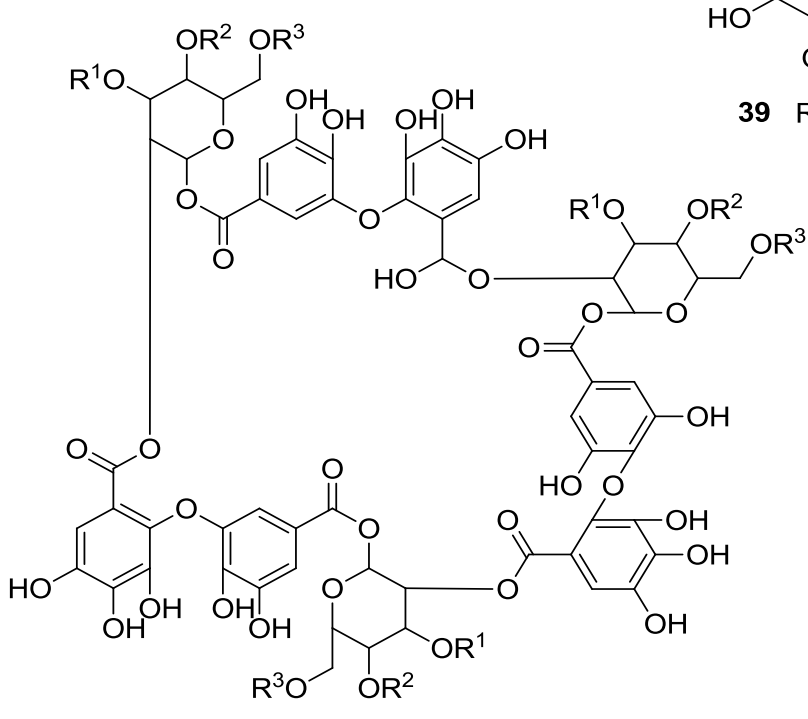<smiles>COC1C(CO)OC(O)C(O)C1O</smiles>

$39 \mathrm{R}^{1}=\mathrm{Gal}$

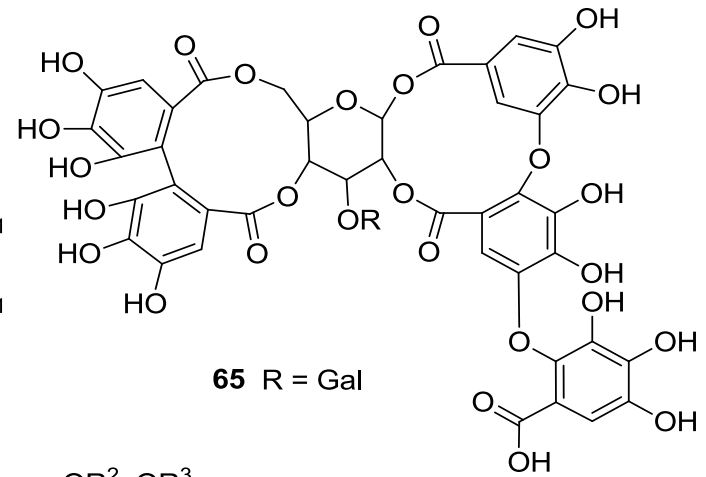

$70 R^{1}=G a l, R^{2}+R^{3}=H H D P$

Where:

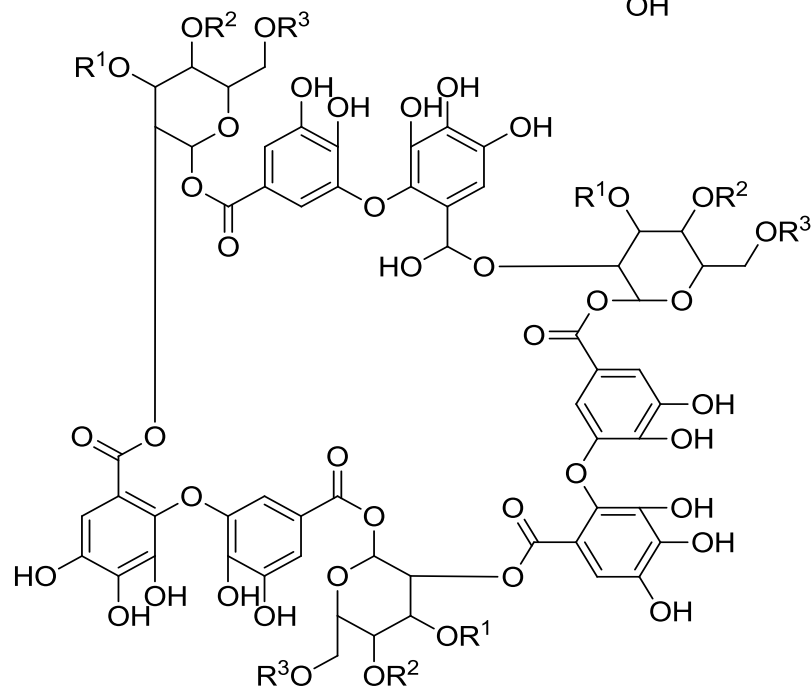

$49 \quad R^{1}=G a l, R^{2}+R^{3}=H H D P$<smiles>CC(=O)c1cc(O)c(O)c(O)c1Oc1c(O)cc(C(=O)O)cc1O</smiles><smiles>O=C(O)c1cc(O)c(O)c(Oc2c(C(=O)O)cc(O)c(O)c2O)c1O</smiles><smiles>O=C(CC(=O)c1cc(O)c(O)c(O)c1O)c1cc(O)c(O)c(O)c1</smiles><smiles>O=C([Hg])c1cc(O)c(O)c(O)c1</smiles>

Figure 3: The structure of ellagitannins isolated from T. nilotica. 


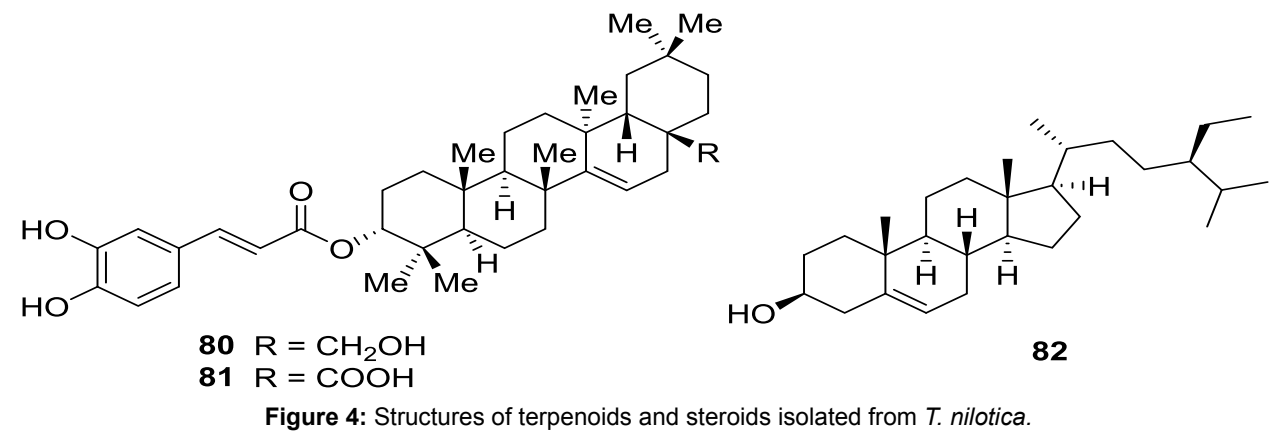

butanol extract from Tamarix nilotic growing in Sudan. The other extracts showed moderate to weak inhibition on fungi (Aspergillus niger and Candidas albicans). The pure compounds (flavone and dihydroflavonol) isolated from butanol extract of Tamarix nilotica also revealed significant antibacterial activity and antifungal activity. This study demonstrated that the butanol fraction of Tamarix nilotica is potential candidate for antimicrobial activity and deserves further optimization [31]. Evaluation of the antimicrobial activities of different extracts and isolated compounds was carried out by the disc diffusion method, measured by the diameter of the zone of inhibition.

Endophytic fungi, which have been reported in numerous plant species, are important components of the forest community and contribute significantly to the diversity of natural ecosystems. Tamarix nilotica grown in Saudi Arabia showed the highest endophytic diversity with a relative frequency of $27.27 \%$, the most frequently isolated species was Penicillium chrysogenum with an overall colonization rate of $98.57 \%$ [48].

\section{Conclusion}

T. nilotica could be considered as promising candidates for the discovery of novel chemopreventive or chemotherapeutic formulations with reduced side effects. The literature endorses further investigations on this plant to determine the active principles and their mode of action.

\section{References}

1. Trease GE, Evans WC (2002) Pharmacognosy, 15th ed., WB Saunders Company Ltd, London.

2. Chaudhary SA (2001) Flora of the Kingdom of Saudi Arabia, Ministry of Agriculture and Water, National Herbarium, National Agriculture and Water Research Center, Riyadh, KSA.

3. Boulos L (1999) Flora of Egypt, Al Hadara Publishing, Cairo, Egypt.

4. Orfali RS (2009) Phytochemical and biological study of Tamarix nilotica growing in Saudi Arabia, Thesis, College of Pharmacy, King Saud University, Saudi Arabia.

5. Villar JL, Alonso MS, Juan A, Crespo MB (2015) Remarks on typification of nineteen names in Tamarix (Tamaricaceae), Nord J Bot 33: 591-600.

6. Sharma SK, Parmar VS (1998) Novel constitutes of Tamarix species. J Sci Ind Res 57: 873-890

7. Abouzid S, Elshahaat A, Ali S, Choudhary MI (2008) Antioxidant activity of wild plants collected in Beni-Sueif governorate, Upper Egypt. Drug Discov Ther 2: 286-288.

8. Orfali RS, Ebada SS, El-Shafae AM, Al-Taweel AM, Lin WH, et al. (2009) 3-O-trans-caffeoylisomyricadiol: A new triterpenoid from Tamarix nilotica growing in Saudi Arabia. Z Naturforsch C 64: 637-643.

9. Bakr RO, El Raey MA, Ashour RS (2013) Phenolic content, radical scavenging activity and cytotoxicity of Tamarix nilotica (Ehrenb.) bunge growing in Egypt. J Pharmacognosy Phytother 5: 47-52.

10. Orabi MAA, Taniguchi S, Sakagami H, Yoshimura M, Amakura Y, et al. (2016) Hydrolyzable tannins of tamaricaceous plants. 7.1 Structures and cytotoxic properties of oligomeric ellagitannins from leaves of Tamarix nilotica and cultured tissues of Tamarix tetrandra. J Nat Prod 79: 984-995.

11. Migahid AM (1978) Flora of Saudi Arabia, 2nd ed., Riyadh University, Riyadh.

12. Drabu S, Chaturvedi S, Sharma M (2012) Asian J Pharm Clin Res 5: 17-19.

13. Akhani H (2014) Tamarix nilotica: The IUCN red list of threatened species: e.T19179434A46081355.

14. Badri MA, Hamed Al (2000) Nutrient value of plants in an extremely arid environment (Wadi Allaqi Biosphere Reserve, Egypt). J Arid Environ 44: 347-356.

15. Booth FEM, Wickens GE (1998) Non-timber uses of selected arid zone trees and shrubs in Africa. Food \& Agriculture Org.

16. Boulos L (2000) Flora of Egypt, Al Hadara, Cairo, Egypt.

17. Villar JL, Alonso MA, Vicente A, Juan A, Crespo MB (2014) The genus Tamarix (Tamaricaceae) in Crete (Greece). Willdenowia 44: 321-326.

18. Ghazanfar S (1994) Handbook of Arabian medicinal plants. CRC Press Inc., United State of America.

19. Nawwar MAM, Buddrus J, Bauer H (1982) Phytochemistry. 21: 1755-1758.

20. Bailey C, Danin A (1981) Bedouin plant utilization in Sinai and the Negev. Econ Bot 35: 145- 162.

21. Elhardallou SB (2011) Cytotoxicity and biological activity of selected Sudanese medicinal plants. Res J Med Plant 5: 201-229.

22. Brown G, Mies B (2012) Vegetation ecology of Socotra. Springer Science \& Business Media.

23. Nawwar MAM, Souleman AMA (1984) 3,4,8,9,10-Pentahydroxy-dibenzo[b,d] pyran-6-one from Tamarix nilotica. Phyrochemistry 23: 2966-2967.

24. Nawwar MAM, Souleman AMA, Buddrus J, Bauet H, Linscheid M (1984) Polyphenolic constituents of the flowers of Tamarix nilotica: The structure of nilocitin, a new digalloylglucose. Tetrahedron Lett 25: 49-52.

25. Barakat HH, Nawwar MAM, Buddrus J, Linsheid M (1987) Niloticol, a phenolic glyceride and two phenolic aldehydes from the roots of Tamarix nilotica. Phytochemistry 26: 1837-1838.

26. Abouzid SF, Ali SA, Choudhary MI (2009) A new ferulic acid ester and othe constituents from Tamarix nilotica leaves. Chem Pharm Bull (Tokyo) 57: 740-742.

27. AbouZid S (2013) Chemical and biological studies on Tamarix nilotica growing in Egypt. Planta Med 79-PI3.

28. El-Sisi HI, Nawwar MAM, Saleh NAM (1973) Plant constituents of Tamarix nilotica leaves (Tamaricaceae). Experientia 29:1064-1065.

29. Nawwar MAM, Souleman AMA, Buddrus J, Linscheid M (1984) Flavonoids of the flowers of Tamarix nilotica. Phytochemistry 23: 2347-2349.

30. Abdel Karim M, Amani H, Inas O, El-Hafez M (2016) Int J of Adv Res 4: 13661372 
Citation: Abdelgawad AAM (2017) Tamarix nilotica (Ehrenb) Bunge: A Review of Phytochemistry and Pharmacology. J Microb Biochem Technol 9: 544-553. doi: 10.4172/1948-5948.1000340

31. Salih AHA (2012) Investigation of the major flavonoids from Tamarix nilotica and Hyphaene thebaica. Thesis, PhD, College of Science, Sudan University of Science and Technology, Sudan.

32. Agrawal AD (2011) Pharmacological activities of flavonoids: A review. Int $J$ Pharm Sci Nanotech 4:1394-1398.

33. Orabi MA, Yoshimura M, Amakura Y, Hatano T (2015) Ellagitannins, gallotannins and gallo-ellagitannins from the galls of Tamarix aphylla. Fitoterapia 104: 55-63.

34. Orabi MA, Taniguchi S, Hatano T (2009) Monomeric and dimeric hydrolysable tannins of Tamarix nilotica. Phytochemistry 70: 1286-1293.

35. Orabi MA, Taniguchi S, Yoshimura M, Yoshida T, Kishino K, et al. (2010) Hydrolyzable tannins of tamaricaceous plants. III. Hellinoyl- and macrocyclictype ellagitannins from Tamarix nilotica. J Nat Prod 73: 870-879.

36. Orabi MAA, Shoko T, Morio Y, Hatano T, Tsutomu H (2010) New monomeric and dimeric hydrolyzable tannins from Tamarix nilotica. Heterocycles 80: 463-475.

37. Orabi MAA, Taniguchi S, Sakagami H, Yoshimura M, Yoshida T, et al. (2013) Hydrolyzable tannins of tamaricaceous plants. V. Structures of monomerictrimeric tannins and cytotoxicity of macrocyclic-type tannins isolated from Tamarix nilotica. J Nat Prod 76: 947-956.

38. Feldman KS (2005) Recent progress in ellagitannin chemistry. Phytochemistry 66: $1984-2000$

39. Thomas CE, Kalyanaraman B (1997) Oxygen radicals and the disease process. Harwood Academic Publishers, Amsterdam, Netherlands.

40. Abouzid S, Sleem A (2011) Hepatoprotective and antioxidant activities of Tamarix nilotica flowers. Pharm Biol 49: 392-395.
41. Kerbel RS (2008) Tumor angiogenesis. N Engl J Med 358: 2039-2049.

42. Hassan LEA, Ahamed MBK, Abdul Majid AS, Baharetha HM, Muslim NS, et al. (2014) Correlation of antiangiogenic, antioxidant and cytotoxic activities of some Sudanese medicinal plants with phenolic and flavonoid contents. BMC Complement Altern Med 14: 1-14.

43. Clawson GA (1989) Mechanisms of carbon tetrachloride hepatotoxicity. Patho Immunopathol Res 8: 104-112.

44. Elobeid MA, Virk P, Siddiqui MI, Omer SA, EIAmin M, et al. (2013) Antihyperglycemic activity and body weight effects of extracts of Emblica officianalis, Tamarix nilotica and cinnamon plant in diabetic male rats. Wulfenia 20: 18-31.

45. Matkowski A, Kuś P, Góralska E, Woźniak D (2013) Mangiferin - A bioactive xanthonoid, not only from mango and not just antioxidant. Mini Rev Med Chem 13: $439-455$.

46. Okeke IN, Laxmaninarayan R, Bhutta ZA, Duse AG, Jenkins P, et al. (2005) Antimicrobial resistance in developing countries. Part I: recent trends and current status. Lancet Infect Dis 5: 481-493.

47. Soltan MM, Zaki AK (2009) Antiviral screening of forty-two Egyptian medicinal plants. J Ethnopharmacol 126: 102-107.

48. Gashgari R, Gherbawy Y, Ameen F, Alsharari S (2016) Molecular characterization and analysis of antimicrobial activity of endophytic fungi from medicinal plants in Saudi Arabia. Jundishapur J Microbiol 9: e26157. 